\title{
Farmers' Attitude to Beneficiary Funding of Extension Services in Kwara State Nigeria
}

\author{
I. Ogunlade, O. I. Oladele* and A. O. Babatunde
}

\begin{abstract}
Department of Agricultural Extension and Rural Development University of Ilorin, Nigeria "Department of Agricultural Extension and Rural Development University of Ibadan, Nigeria E-mail: oladele20002001@yahoo.com,iogunlade@yahoo.com
\end{abstract}

\author{
KEYWORDS Farmers. Funding.Extension Services. Attitude. Nigeria
}

\begin{abstract}
Beneficiary funding for agricultural extension services in many developing countries, including Nigeria is not only a reality, but also a necessity due to several factors. This study was carried out in Kwara state. Specifically, it examined the socio-economic characteristics of the contact farmers, forms of service that have been rendered by the agricultural extension service agency to the contact farmers, the perceived usefulness of innovations pushed by extension service agency and sustainable funding for extension service through the beneficiaries. Sample selection was done through a combination of purposive and random sampling to allow for equal opportunities among contact farmers. Data for the study were collected through the use of interview schedule. Data analyses showed that 58.5 percent of the respondents are literate with a mean annual income of N143,774.19. Majority (72.9 percent) of the respondents inherited their farmlands while 61.4 percent cultivated less than 5 hectares of farmland. Findings of the study further revealed that 32.9 percent of the respondents have less than 10 years of farming experience, while more than half (52.9 percent) made regular contacts with extension agents and 87.1 percent are members of different farm organizations. Farm size and education make a statistically significant contribution in explaining sustainable funding among farmers.
\end{abstract}

\section{INTRODUCTION}

In Nigeria, the World Bank has been the main financier (till 1994) of the Agricultural Development Projects (ADPs) and their extension service sub-programmes (Mensah 1995; Apantakatu et al.. 2000). The Federal and State Governments in Nigeria have also been permanently financing the ADPs and extension services. The other external donors included International Fund for Agricultural Development (IFAD), Integrated Reconstruction Development Project (IRDP), Food and Agricultural Organization of the United Nation (FAO) and European Union. Werblow (1996) reported that more than 60 percent of the European Union (EU) development funds were allocated to National Aid Programmes for agricultural extension services and rural development. The World Bank component of the tripartite funding arrangement (with Federal and state Governments) for the ADPs in Nigeria ceased in 1995. Most of the ADPs have been unable to cope with their primary responsibilities of providing agricultural extension services in their domain. Many of them have developed coping strategies such as staff reduction, irregular Monthly Technology Review Meetings (MTRM), forthnight training (FNT), and are still unable to cope.
Farrington (1994) indicated that Community Based Associations (CBAs) and farmer groups in Ecuador, Botswana, Columbia, Senegal, Mali and South America have the potentials and could actually play joint roles in agricultural research and extension. Farmers organization (FO) support the livelihood strategies of the rural poor. The formation and action of groups, such as CBAs, FOs and Non Governmental Organization (NGOs) had a long history going back to commu-nity development programme which brought particular challenges and possibilities such as strengthening rural civil society, increasing and people's development initiatives, which are what make a focus on groups consistent with donor priorities (Dugue 1993). Trujillo (1993) stated that extension service in some Latin America countries are moving towards self-financing. Some of the potential benefits of this are higher adoption rate, wider discussion of new innovations among farmers and researchers becoming aware and closer to farmers' ideas and characteristics. Farrington (1994) implied that adaptive research and extension could be financed by farmers group controlled resources. It was also recommended that such farmer groups be represented on the boards of those agencies they have funded.

Apantaku and Fakoya (2000) concluded that CBAs may be veritable and sustainable tools for 
bringing about rural and agrarian community developments in Southern Western Nigeria. Their objectives are based on selfless and overall development of their community. They have been known to participate in government development programmes. Members may be willing to participate in counterpart-funding extension services. Religions organisations such as the Diocesan Agricultural Development Project in Ijebu area of Ogun state are deeply involved in funding and carrying out extension services (Adedoyin and Patrick-Ngoyi 1996). Churches and Muslim organizations may also be willing to assist the states in funding extension. Vincent (1995) concluded that three elements are essential in financing Development Organizations (DOs) and NGOs development programmes. These are their own funds; grants and financing by local or international donors/agencies; and funds and capital from banks. Five local financial resources were identified. These are local elites, religious communities and churches, local entrepreneurs, local foundations and local governments. Kidd et al. (1998) states that in 1946, the United Kingdom government established an agricultural service in order to follow a policy of self-sufficiency in food for the country after World War II. Thus agricultural service activities were adult education to improve skill and knowledge, advisory services to assist farmers, make deci-sions. These services wee initially provided free to all farmers. However, with dwindling funding from government, pressures were mounted on agricultural service towards cost- recovery and privatization. Presently, clients of ADAS pay for services, which they used to receive free of charge.

Public sector extension, facing criticisms for its cost and its lack of efficiency and for not pursuing programmes that foster equity, is confronted with a number of possibilities for change. There has been a trend, perceptible throughout various extension systems undergoing adjustment, of greater flexibility and multiple partners in funding agricultural advisory services (OECD 1989). Three major policies adopted by government and farm organization regarding privatization of extension include: public financing by the tax payer only for the kinds of services that are of direct concern to the general public; direct charging for some individual services with direct return (in the form of improved income and mixed funding shared between public and private professional association contributions for some services where benefits are shared (Hoffmann et al. 2000)

A pervading development in new forms of financial support for extension is the trend to mixed sources of funding, reflecting strategies to gain access to additional sources of funding. In several developing countries, public and private coordination is already established. Alternative patterns indicate a fostering of private corporate initiative, encouraging cooperative ventures by farmers, coordinating public - private extension services and privatizing the public system (Wilson 1991). The need for improved and expanded extension activities, together with a strengthening philosophical view of less government involvement in national economics, has led to a number of strategies for changing the way extension services are delivered. In analyzing the core functions of the state and through some initial experiences, there is a growing understanding of the range of possibilities, which exist for public private interaction in agricultural extension (Maalouf et al. 1991). This is still; however, far from a good appreciation of how interaction can best exist in different contexts. In looking further to a wider range of stakeholders, there is also a growing movement which seeks to increase the level of user participation in all aspects of life and which has made decentralization and the creation of a civil society as key components of the new policy agenda. Unfortunately, it seems that many proposals on institutional frameworks required for enhancing the role of farmers in agricultural extension are rather anecdotal. Much is written on increasing the level of participation of farmers, a critical issue for extension, and this has led to calls for public agricultural extension provision to be more demand driven. The objective of this paper is to determine the attitude of farmers to beneficiary funding of extension services in Kwara State Nigeria

\section{METHODOLOGY}

The study was carried out in Kwara state of Nigeria which is situated between latitudes 7.20 and $1105^{\circ}$ north of the equator and between longitudes 2.5 and $645^{\circ}$ East of the prime Meridian in the Mid-North-Western part of Nigeria. It is bounded in the North by Sokoto and Niger states, and the Federal Capital Territory, and in the South by Oyo, Osun, Ekiti and Edo States. The western boundary is Republic of Benin, while the eastern 
boundary consists of Plateau and Benue states. Kwara state has a population of 1.57 million (NPC, 1991 ) and a land area of about 32,500 square kilometers with three main ethnic groups, namely, Yoruba, Nupe and Baruba (KWADP 2000), with the climate being intermediate between the extremes of dryness, coolness and hotness. The mean monthly rainfall ranges between $50.8 \mathrm{~mm}$ during the wettest months and $24.13 \mathrm{~mm}$ during the driest period. The driest months are from January to March, while the rains last from May to September with occasional drizzles in October. The minimum average temperature through out the state ranges between $21^{\circ} \mathrm{C}$ while maximum average temperature ranges approximately between $30^{\circ} \mathrm{C}$ and $35^{\circ} \mathrm{C}$ (KWADP 2000)

According to Kwara Agricultural Development Project (KWADP) impact study report for 1989$1993,75 \%$ of Kwara state population lives in the rural areas. Over $90 \%$ of the rural population engage in various sizes and forms of agricultural activity. The state has about 185,000 farm families with an average of 6 or 7 people per farm family. The state is divided into four zones (A,B,C,D) by the KWADP. The target populations for the study were contact farmers of the KWADP, and extension agents in the $\mathrm{B}$ and $\mathrm{D}$ zones. The sample selection was done through a combination of purposive and random sampling to allow for equal opportunities among contact farmers. Data collected for the study were coded and analysed with frequency counts, percentages and Multiple regression analysis using Statistical Package for Social Sciences (SPSS). The general form of the regression model is given as:

$\mathrm{Y}=\mathrm{b}_{0}+\mathrm{b}_{1} \mathrm{X}_{1}+\mathrm{b}_{2} \mathrm{X}_{2}+\mathrm{b}_{3} \mathrm{X}_{3}+\mathrm{b}_{4} \mathrm{X}_{4}+\mathrm{b}_{5} \mathrm{X}_{5}+\mathrm{b}_{6} \mathrm{X}_{6}+\mathrm{b}_{7} \mathrm{X}_{7}$ $+\mathrm{b}_{8} \mathrm{X}_{8}+\mathrm{b}_{9} \mathrm{X}_{9}+\mathrm{e}_{\mathrm{t}}$

Where: bo is constant term

$\mathrm{b}_{1} \ldots \ldots \ldots \mathrm{b}_{9}=$ coefficient of regression

$\mathrm{Y}=\quad$ Sustainable funding (dependent variable)

$\mathrm{X}_{\mathrm{n}}=\quad$ Explanatory variables

$\mathrm{X}_{1}^{\mathrm{n}}=$ Age

$\mathrm{X}_{2}=$ Education

$\mathrm{X}_{3}=$ Farm size

$\mathrm{X}_{4}=$ Farming Experience

$\mathrm{X}_{5}^{4}=$ Labour cost

$\mathrm{X}_{6}=$ Income

$\mathrm{X}_{7}=$ Extension contact

$\mathrm{X}_{8}=$ Farm practices

$\mathrm{X}_{9}=$ Farm advice/skills

$\mathrm{e}_{\mathrm{t}}=$ Error term/disturbance term

\section{RESULTS AND DISCUSSION}

Findings in Table 1 indicate that 38.6 percent of the farmers are less than 40 years of age, majority ( 54.3 percent) of the farmers fall between the ages 40-50 years, while those that fall above 50 years of age represent 7.1 percent. The 38.6 percent can be considered young, while the 54.3 percent of the farmers are middle aged and only 7.1 percent are considered to be old chronologically. The implication here is that, the young and the middle aged farmers whom one would expect to be in urban centre, looking for white collar jobs decide to stay in the rural areas to practice farming. Of great interest to this study is that these young farmers are agile, manipulative, progressive, mobile and willing to assist other farmers passing on agricultural information.

Farmers' educational levels are varied as 30 percent of the farmers claimed that they did not have formal type of education, 11.4 percent claimed to have Quranic education. Furthermore, 18.6 percent of the farmers reported that they had primary school education, 15.7 percent had secondary school education and 24.3 percent had post secondary school education at the time of study. When combined together 58.6 percent of the farmers are literate in the study area. It can be assumed that with this high literate value of the respondents, they will be well oriented towards rendering positive assistance on sustainable funding for extension service agency.

It is also observed in Table 1 that 32.9 percent of the farmers have less than 10 years of farming experience, while 28.5 percent of the farmers reported that their farming experience falls between $10-20$ years. Furthermore, 38.6 percent of the farmers have farming experience greater than 20 years. The mean years of experience was 18.5. Of interest to this study is that majority of the farmers are young, and may be able to cultivate larger hectares of farm land which may lead to higher yield and income. For example 61.4 percent of them cultivated less than 5 hectares of farmland. 28.6 percent of the farmers cultivated between 5.1-10 hectares of farm land while 8.5 percent cultivated between 11-15 hectares of farm land. It is also observed from the same table that 1.4 percent of the farmers cultivated between more than 15 hectares of farmland. In general, majority of the farmers cultivated reasonable size of farmland. This may be due to the method of land acquisition in the study area. That is, it is not the 
practice of landowners to sell farmland to an interested farmer as land is communally owned and not personalized. An interested farmer can cultivate land belonging to another family or an individual in the village as long as permitted. Also, majority of the respondents acquired their farmland through inheritance. This is evident in Table 1 where the majority of the farmers (72.9 percent) indicated that they inherited their farmlands. This practice implies that they are free to cultivate as much land as they can. Furthermore, the availability and use of tractors provided by the Kwara state Agricultural Development Projects and the Local Government Department of Agriculture made it easier for farmers to cultivate and increase crop production.

Majority of farmers (72.9 percent) inherited their farmland from their parents, while 5.7 percent bought their farmland and 21.4 percent got their farmland through leasing from the landowners. About 37 percent of the farmers had annual income of less than N50,000 and these formed the majority of the population, while 15.8 percent earned between N50,000 - N150,000 annually from their farm. Furthermore, 18.4 percent reported that they had average annual income between $\mathrm{N} 151,000-\mathrm{N} 250,000$, while 8.5 percent reported that they have annual income in the range of $\mathrm{N} 251,000-\mathrm{N} 350,000$ and another 8.5 percent earned more than $\mathrm{N} 350,000$ from their farm in a year. One will not be surprised to see 11.4 percent of the farmers refused to disclose their annual income. The possibility is that these farmers refused to disclose their income purposely because they feared that the disclosures either might affect the assessment of their tax or for security reasons. Also farmers have a mean annual income of N143,774.19. Majority (64.2 percent) of the farmers spent less than N50,000 per year on hired labour, 12.8 percent between N51,000 N100,000 on hired labour, 11.3 percent spent between N101,000 - N150,000 and 4.3 percent spent between N151,000 - N200,000 annually on hired labour. The findings also show that 7.1 percent of the farmers were not ready to disclose or cannot estimate how much they spent on hired labour. From the findings of this research, it can be suggested that farmers with higher labour cost are likely to belong to the group of farmers with large farm sizes and those with low labour cost may be linked with low farm sizes. Also, the high figures for labour costs may be attributed to general inflation in the country with the attendant general rise in prices of goods and services, including labour costs which had appreciated and lastly because of the decrease in the value of naira, the nation's currency.

Agricultural extension agency is not able to perform its duty effectively due to insufficient funding of its services. The farmers in the study area were asked to indicate areas they will be willing to assist the agency. Table 2 shows the mean scores distribution of farmers on areas in

Table 1: Frequency and percentage distribution of farmers by their socio-economic characteristics. Socio-economic characteristics frequency percentage

\begin{tabular}{|c|c|c|}
\hline $\begin{array}{l}\text { Socio-economic } \\
\text { characteristics }\end{array}$ & Frequency & Percentage \\
\hline \multicolumn{3}{|l|}{ Age (years) } \\
\hline$<40$ & 27 & 38.6 \\
\hline $40-50$ & 38 & 54.3 \\
\hline$>50$ & 5 & 7.1 \\
\hline Total & 70 & 100.0 \\
\hline \multicolumn{3}{|l|}{ Educational Level Attained } \\
\hline No formal Education & 21 & 30.0 \\
\hline Quranic Education & 8 & 11.4 \\
\hline Primary Education & 13 & 18.6 \\
\hline Secondary Education & 11 & 15.7 \\
\hline Post Secondary Education & 17 & 24.3 \\
\hline Total & 70 & 100.0 \\
\hline \multicolumn{3}{|c|}{ Length of Farm Experience (Years) } \\
\hline$<10$ & 23 & 32.9 \\
\hline $10-20$ & 20 & 28.5 \\
\hline$>20$ & 27 & 38.6 \\
\hline Total & 70 & 100.0 \\
\hline \multicolumn{3}{|l|}{ Farm Size } \\
\hline$<5$ ha & 43 & 61.4 \\
\hline $5.1-10$ ha & 20 & 28.6 \\
\hline $10.1-15$ ha & 6 & 8.5 \\
\hline$>15$ ha & 1 & 1.4 \\
\hline Total & 70 & 100.0 \\
\hline \multicolumn{3}{|l|}{ Farmland Acquisition } \\
\hline Inheritance & 51 & 72.9 \\
\hline Bought & 4 & 5.7 \\
\hline Lease & 15 & 21.4 \\
\hline Total & 70 & 100.0 \\
\hline \multicolumn{3}{|l|}{ Annual Income } \\
\hline$<50,000$ & 26 & 37.2 \\
\hline $50,000-150,000$ & 11 & 15.8 \\
\hline $151,000-250,000$ & 13 & 18.4 \\
\hline $251,000-350,000$ & 6 & 8.5 \\
\hline$>350,000$ & 6 & 8.5 \\
\hline Don't know & 8 & 11.4 \\
\hline Total & 70 & 100.0 \\
\hline \multicolumn{3}{|l|}{ Labour Cost Per Year $(N)$} \\
\hline$<50,000$ & 45 & 64.2 \\
\hline $50,000-100,000$ & 9 & 12.8 \\
\hline $101,000-150,000$ & 8 & 11.3 \\
\hline $151,000-200,000$ & 3 & 4.3 \\
\hline Don't know & 5 & 7.1 \\
\hline Total & 70 & 10.0 \\
\hline
\end{tabular}


which they are wiling to assist the extension agency to effectively perform its duty. The highest mean of sustainability is on mobilizing other farmers/beneficiaries to contribute similar assistance to extension agents (4.68). Others with high sustainable funding index are assurance of prompt and positive response to extension agent at every visit (4.64); provision of food and drinks for extension agents at every visit (4.61); provision of village accommodation for extension agents (4.58), "provision of motorbikes for extension agents to increase their coverage (4.48), contribute money to the cost of result demonstration (4.11); bear the expenses and contribute money to the cost of excursion (Agric. Tours) and field trips (4.08), pay to participate in method demonstration programme (4.07) and meal subsidy for extension agents' (3.97).

These high means on a five point likert type scale suggests that respondents were willing to contribute to sustainable funding for extension service. Furthermore, the lowest means of sustainability were obtained from fuel the car as the case may be (3.30), pay for handbills, posters, leaflets that contain valuable information on farm productivity, (3.24) pay for agricultural film shows (3.20), and contribute money to the cost of radio programme (3.35). The overall mean rating of the additional funding by farmers suggests that they were willing to support the funding for extension service in order to make it sustainable.

In an effort to derive the relationship between selected socio-economic characteristics of farmers and sustainable funding,. Multiple regression analysis was used to examine the relationships between sustainable funding, as the dependent variable and nine variables: age, education, farm experience, income, labour cost, usefulness of farm advice, extension contact, and farm innovations. The dependent variable, sustainable funding, was measured by using farmers' response on questions about their willingness to assist the extension agency. This variable was coded on a five point scale where 5 indicates "Strongly Agree", 2 indicates "Agree", 4 indicates "Undecided", 2 indicates "Disagree", and 1 indicate "Strongly Disagree".

When entered into a stepwise multiple regression equation, it was found that two variables explained $33.6 \%$ of the total variance of farmers' willingness in sustainable funding. Farm size and education make a statistically significant contribution in explaining sustainable funding among farmers (Table 3). The most important variable in explaining the variance was farm size $(\mathrm{B}=.471)$, which means that a strong and positive correlation exist between farm size and willingness to contribute to sustainable funding. This is to

Table 2: Farmers ratings on sustainable funding for agricultural extension service.

\begin{tabular}{lc}
\hline Funding Provisions (Mechanisms) & Mean scores \\
\hline Mobilizing other farmers/beneficiaries to contribute similar assistance to & 4.68 \\
Extension Agent (EA) & 4.64 \\
Assurance of my prompt and positive response to EA at every visit. & 4.61 \\
Provision of food and drinks for EA at every visit & 4.58 \\
Provision of village accommodation for EA & 4.48 \\
Provision of motorbikes for EA to increase their coverage. & 4.11 \\
Contribute money to the cost of result demonstration & 4.08 \\
Bear the expenses and contribute money to the cost of & $2^{\text {th }}$ \\
excursions (Agric tours) and field trips & 4.07 \\
Contribute to participate in method demonstration programme & 3.97 \\
Meal subsidy for EA & 3.70 \\
Pay for EAs accommodation in the nearest town & 3.55 \\
Undertake the transportation and/ or cost for an EA. & 3.54 \\
Pay allowance for EAs visit to my farm. & 3.48 \\
Pay allowance for EAs visit to my home & 3.47 \\
Pay honourarium to invited Subject Matter Specialists MS speakers (Lecturers) & $5^{\text {th }}$ \\
at lectures, group discussions, workshops and seminars & $7^{\text {th }}$ \\
Contribute money to the cost of radio programme & $8^{\text {th }}$ \\
Fuel EA's vehicle as the case may be & 3.35 \\
Pay for handbills, posters, leaflets that contain valuable information & 3.30 \\
on farm productivity & 3.24 \\
Pay for agricultural film shows & $10^{\text {th }}$ \\
\hline Note:Raking obain & $12^{\text {th }}$ \\
\end{tabular}

Note: Ranking obtained from Likert - type scale are strongly Agree $=5$, Agree $=4$, Undecided $=3$, Disagree $=2$, Strongly Disagree $=1$. 
Table 3: Stepwise multiple regression of selected socio-economic variables on sustainable funding for extension service.

\begin{tabular}{lcc}
\hline Variable & $\begin{array}{c}\text { Coefficient } \beta \\
\text { (Beta) }\end{array}$ & $t$ \\
\hline Farm size & $0.471^{*} *$ & 4.113 \\
Education & $0.334^{*} *$ & 3.120 \\
Farm experience & 0.161 & 1.322 \\
Income & 0.146 & 1.087 \\
Labour cost & 0.113 & 0.801 \\
Farm advice (Usefulness) & -0.051 & -0.447 \\
Extension Contact & 0.024 & 0.214 \\
Farm Practice (Innovation) & 0.023 & 0.199 \\
Age & 0.007 & 0.061 \\
$\mathrm{~F}$ & 14.4 & \\
$\mathrm{R}^{2}$ & 33.6 & \\
$\mathrm{p}$ & $<.05$ & \\
\hline
\end{tabular}

say that as farmers cultivate more hectares of farm lands there is increase in their willingness to contribute to sustainable funding. The second and last variable in the model, level of education ( $\mathrm{B}=.334)$ was positively correlated with farmers' sustainable funding. In this case, as farmers attained higher levels of education, the higher the willingness to contribute to sustainable funding.

\section{REFERENCES}

Adedoyin SF, Patrick-Ngoyi A 1996. Diocesan ADP: An Extension Communication strategy of Ijebu-Ode Catholic Diocese for promoting sustainable Rural Development. In: Identification Of Internal Donors for Funding Agricultural Extension Service in Osun State, pp. 10-12.

Apantaku SO Fakoya EO 2000. Influence of community based associations in promoting community development in rural areas of Southwestern Nigeria. Journal of Extension Systems, 16: 47 - 60.

Apantaku SO Sodiya CI Apantaku FS Fakoya EO 2000. Alternative internal sources of funds for extension service in Ogun State. Nigerian Journal of Sustainable Agriculture, 17(1): 37 - 54.

Dugue P 1993. The Senegalese Institute for Agric Research and the Fatick Region Farmers Association, IRSA, pp. $270-282$.

Farrington J 1994. Public Sector Agricultural Extension: Is there Life after structural Adjustment. Natural Resources Perspectives No 2 ODI London, pp. 4-7.

Hoffmann V, Lamers J, Kidd A 2000. Reforming the organization of agricultural extension in Germany: Lessons for other countries. AgREN Network Papers, 596: 1-20.

Kidd A, Lamers J, Hoffmann V 1998. Towards Pluralism in Agricultural Extension - A growing Challenge to the public and private sectors. Agriculture Development, 1: 9 .

KWADP 2000. Kwara State Agricultural Development Project Annual Report, pp. 3-7.

Maalouf WD, Contado TE, Adhikarya R 1991. Extension coverage and resource problems: the need for public - private cooperation. In: WM Rivera, WDJ Gustafson (Eds.): Agricultural Extension: Worldwide Institutional Evolution and Forces for Change. Amsterdam: Elsevier, pp. 12-18.

Mensah MC 1995. Funding agricultural extension. In: JN Wolf (Ed.): Agricultural Extension in Africa. Proceedings of an International Workshop on Agricultural Extension in Yaounde. Cameroon: CTA, pp. 26-32.

OECD (Organisation of Economics Cooperation and Development) 1989. Survey On Effects and Consequences of Different Forms of Funding Agricultural Services. Paris: OECD doc. AGR/REE 89, 7. pp.15-17.

Trujillo G 1993. The El Ceibo regional agricultural and agro-industrial cooperative coordinating committee. In: AJ Bebbington, $G$ Thiele (Eds.): NonGovernmental Organizations and the State in Latin America. London: Routledge, pp. 20-35.

Vincent F 1995. Alternative financing of third World Development Organisations and NGOs. Geneva: IRED, pp. 56 - 98.

Wilson M 1991. Reducing the costs of public extension services: Initiatives in Latin America. In: W Rivers, Dan Gustafsen (Eds.): Agricultural Extension Worldwide: A Critical Turning Point, Agricultural Extension: Worldwide Institutional Evolution and Forces For Change. New York: Elsevier, pp. 55-99. 